\title{
Energy Efficient Semi-Automatic Car Parking System using Raspberry -Pi
}

\author{
Hemalatha, Sowmiya Manoj, Ramya
}

\begin{abstract}
In latest days, the amount of cars has risen dramatically. As a result, free parking space has become a issue, particularly in metros. This raises the demand for the development of a semi-automated car parking system, which makes effective use of room and prevents traffic congestion. But the operation and maintenance of such a car parking system is very difficult. Earlier, the parking spaces available for parking were tracked by human staff, which was very time consuming. Here, we have created a semi-automatic parking scheme that provides a distinct parking slot for each vehicle. Therefore, the driver does not need to search for a vacant slot. This scheme also requires less manpower. Any number of cars entering or leaving the zone at the same time may also be accommodated. This stops the driver from stopping at the door. The system is extremely energy efficient by turning on the lamps in the parking area only when the vehicle is on the move, which makes it distinct from most parking schemes. A research on current systems shows that there are automated systems based on sensor networks or video systems that monitor the existence of vehicles and the accessibility of free parking spaces. They lack the benefit of giving each vehicle a distinctive slot, thus generating confusion when many vehicles arrive at the same time.
\end{abstract}

Keywords: Raspberry -Pi, LCD display

\section{INTRODUCTION}

A significant risk to vehicle owners today is that they are in continual fear of having their cars robbed from a prevalent parking lot or from a parking lot outside their homes.In cities,street lights consume a large amount of energy, using nearly half of the city's energy[2],[4],[6]. An intelligent street light management system can be designed based on LED lamps and wireless communication technologies and installed in the cities[7],[9],[11]. It will take only an initial cost of investment for replacing the traditional system. Later, the power consumption is very less. This system detects the flow of vehicles and varies the intensity of LED lamps as per the traffic flow. The street lights can be monitored and controlled using this system. Faults in the lamps can also be identified through wireless technology.

Revised Manuscript Received on August 22, 2019

Hemalatha, Department of Electronics and Communication Engineering, Bharath Institute of Higher Education and Research, Chennai, Tamilnadu, India. E Mail - contacthemab@gmail.com

Sowmiya Manoj, Department of Electronics and Communication Engineering, Bharath Institute of Higher Education and Research, Chennai, Tamilnadu, India. E Mail -sow_anu @yahoo.com

Ramya, Department of Electronics and Communication Engineering, Bharath Institute of Higher Education and Research, Chennai, Tamilnadu, India. E Mail -ramyasamdra@gmail.com

\section{SYSTEM WORKING}

\section{A. Existing system}

The existing traditional street lighting system consumes electricity throughout whole night in the parking area. To overcome this problem and for saving electricity a new intelligent street lighting system has been proposed. This system uses IR sensorswhich switches light of parking area according to the motion detected. Technologically system is simple, accurate and maintainable[8],[10],[12].

\section{B. Proposed system}

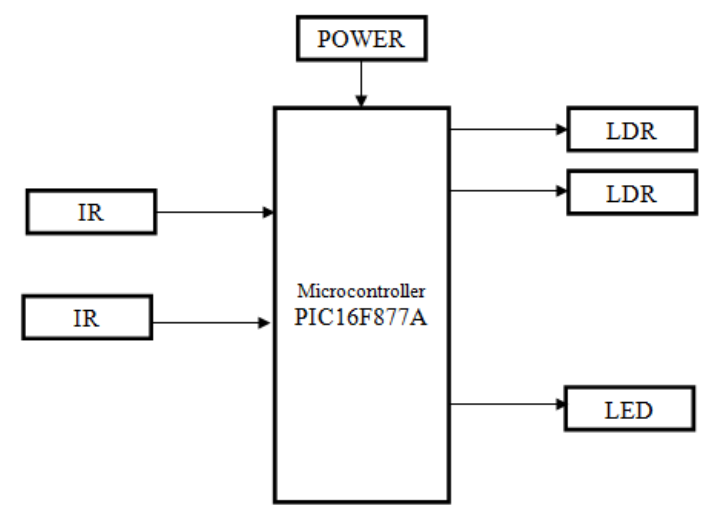

Fig 1 Block Diagram (proposed system)

The so called system carried of the car parking system and street light control using the PIC16F877A Microcontroller.The car parking system having the IR sensor to detect the vehicles count and display using the LCD in the entrance of the car parking lot[13],[15],[17].

Whenever the vehicle is detected, the empty space will be displayed in the LCD and The Car parking availability will be shown using LED's intimation. When the vehicle is moving, we can able to switch on the light automatically then after leaving the vehicle we can switch of the vehicle.At the day time, LDR sensor detect automatically, it will switch of the light, then at the night time, we can able to switch on the light.The raspberry pi is used to the control the gate and light systems using the IOT applications[1],[3],[5]. 


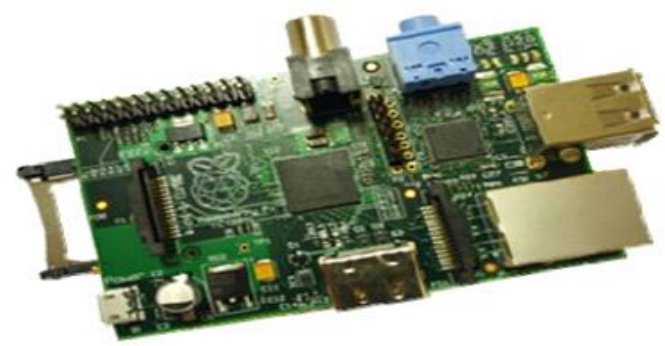

Fig 2 Raspberry Pi Board

\section{RESULT AND DISCUSSION}

Cars can only join one by one in traditional PLC programming. Any amount of vehicles may enter or exit at the same moment in this scheme. In addition, Raspberry Pi has the benefit of serial communication that allows several processors to be linked. This allows the system to be extended to many more routes and slots. Various possible instances of vehicles entering and leaving have been regarded for algorithm development and are outlined below[14],[16],[18].

1. Several vehicles leaving many vehicles at the same moment could leave the slots to the exit at the same moment. The adjacent lights are held on until the vehicles are in movement. The program shall ensure that the unused slots are allocated to the vehicles arriving later. Cars can leave from any slot in any order[19],[20].

2. The vehicle is entering the parking lot while another vehicle is leaving.The total number of available slot is displayed on the LCD display.

3. As parking slot may or may not be full so, it can be easily expressed through green and red LEDs at just outside of each cabin / parking slots.

4. When car moves in the parking area surrounding light are fully automated as vehicles are detected by the IR sensor then front two LEDS at both end of street starts glowing while other remains off and as vehicles moves further ahead of IR sensor LEDs of back is goes of and front LEDs of next to that starts glowing and the process repeats till the end.

5. "Parking Full" is exhibited when a vacant slot is not accessible. The adjacent lights are off when needed if no movement is detected by the IR detector.

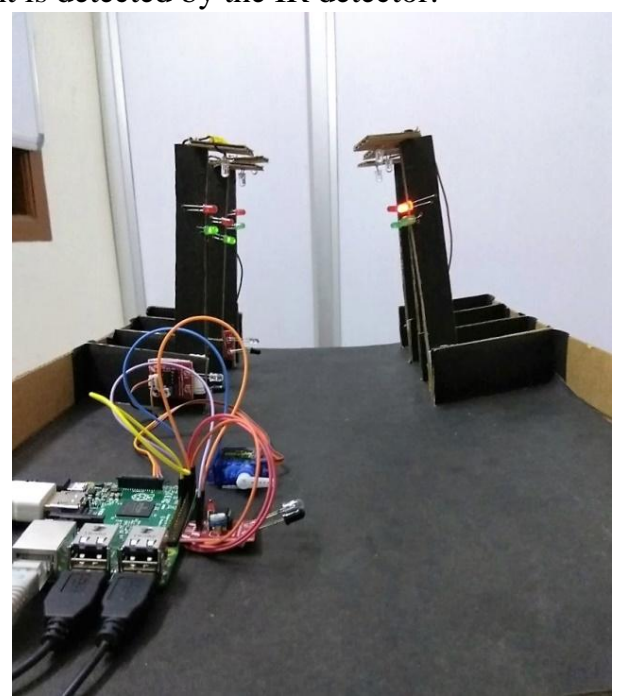

Fig 3. Front view of model with Raspberry Pi IOT gate control

\section{CONCLUSION}

Raspberry pi in our project can be modified to an extreme level at the same time it can be used for connecting many things such as it is easily compatible with cameras and as well as some other sensors also.

\section{REFERENCES}

1. Kongkham, D. \& Sundararajan, M. 2019, "Distributed wideband sensing method for faded dynamic spectrum access", International Journal of Innovative Technology and Exploring Engineering, vol. 8, no. 10 , pp. 4309-4312.

2. Balaji, S., John Paul Praveen, A. \& Mohanraj, R. 2019, "Recognizable proof and analysis of palm print in biometric authentication system using bayes techniques", International Journal of Innovative Technology and Exploring Engineering, vol. 8, no. 9 Special Issue 3, pp. 1126-1129.

3. Kavitha, G., Priya, N., Velvizhi, R. \& Allin Geo, A.V. 2019, "Parallel computation in correspondence and signal processing", International Journal of Innovative Technology and Exploring Engineering, vol. 8 , no. 9 Special Issue 3, pp. 1136-1139.

4. Hema, R., Sundararajan, M. \& Balaji, S. 2019, "Smartphone control robot with automatic firing gun", International Journal of Innovative Technology and Exploring Engineering, vol. 8, no. 9 Special Issue 3, pp. 625-627.

5. Kaliyamurthie, K.P., Sundar Raj, B., Velvizhi, R. \& Shanmugapriya, K. 2019, "Dual band paper substrate CPW antenna for wireless applications", International Journal of Innovative Technology and Exploring Engineering, vol. 8, no. 9 Special Issue 3, pp. 605-608.

6. Geo, A.V.A., Arunachalam, A.R., Michael, G. \& Elankavi, R. 2019, "Evaluating architecture using compact modalities", International Journal of Innovative Technology and Exploring Engineering, vol. 8, no. 9 Special Issue 3, pp. 836-838.

7. Theivasigamani, S., Jeyapriya, D. \& Anita Davamani, K. 2019 , "Anamoly analyzing and exploring for wireless sensor networks", International Journal of Innovative Technology and Exploring Engineering, vol. 8, no. 9 Special Issue 3, pp. 1116-1118.

8. Jeyapriya, D., Theivasigamani, S., Velvizhi, R. \& Nandhini, P. 2019 "Program detection in wireless feeler networks", International Journal of Innovative Technology and Exploring Engineering, vol. 8, no. 9 Special Issue 3, pp. 1194-1195.

9. Gowri Sankaran, B., Karthik, B. \& Vijayaragavan, S.P. 2019, "Image compression utilizing wavelet transform", International Journal of Innovative Technology and Exploring Engineering, vol. 8, no. 10, pp. 4305-4308.

10. Gowri Sankaran, B., Karthik, B. \& Vijayaragavan, S.P. 2019, "Weight ward change region plummeting change for square based image huffman coding", International Journal of Innovative Technology and Exploring Engineering, vol. 8, no. 10, pp. 4313-4316.

11. Hema, R., Sundararajan, M. \& Balaji, S. 2019, "Smartphone control robot with automatic firing gun", International Journal of Innovative Technology and Exploring Engineering, vol. 8, no. 9 Special Issue 3 pp. 625-627.

12. Rangaswamy, K. \& Rajabhushanam, C. 2019, "Congestion control in wireless network using TCP friendly rate control (TFRC)", International Journal of Recent Technology and Engineering, vol. 8 , no. 2 Special issue 3, pp. 1598-1602.

13. Tamil Selvan, S. \& Sundararajan, M. 2019, "Performance Parameters of 3 Value 8t Cntfet Based Sram Cell Design Using H-Spice", International Journal of Recent Technology and Engineering, vol. 8, no. 2 Special issue 5, pp. 22-27.

14. Vinoth, V.V. \& Kanniga, E. 2019, "Steganographical techniques in hiding text images - system", International Journal of Recent Technology and Engineering, vol. 8, no. 2, pp. 6535-6537.

15. Saravana, S., Balaji, S., Arulselvi, S. \& John Paul Praveen, A. 2019 "Reliable power quality monitoring and protection system", International Journal of Innovative Technology and Exploring Engineering, vol. 8, no. 9 Special Issue 3, pp. 644-645.

16. Sundaramoorthy, A. \& John Wiselin, M.C. 2019, "Single patch antenna with multiple feed", International Journal of Innovative Technology and Exploring Engineering, vol. 8, no. 9, pp. 1743-1747.

17. Velavan, R., Bharanidharan, S. \& Sheeba, B. 2019, "EMF pollution Causes, effects and protection", International Journal of Innovative

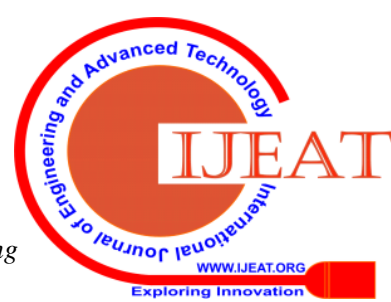


Technology and Exploring Engineering, vol. 8, no. 9 Special Issue 3, pp. 1166-1168.

18. Veer, R.A., Arulselvi, S. \& Karthik, B. 2019, "Construction of ensemble square classification approaches in MIMO OFDM", International Journal of Engineering and Advanced Technology, vol. 8, no. 5, pp. 2039-2041.

19. Agitha, W. \& Kaliyamurthie, K.P. 2019, "Improved energy efficient in WBAN using MAC with cloud computing", International Journal of Innovative Technology and Exploring Engineering, vol. 8, no. 8, pp. 2405-2408.

20. Kastro, G.G. \& Wiselin, M.C.J. 2019, "Design and analysis of stub loaded resonator", International Journal of Recent Technology and Engineering, vol. 8, no. 1 Special Issue4, pp. 272-283.

\section{AUTHORS PROFILE}

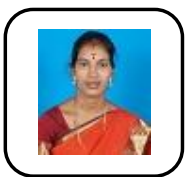

Hemalatha, Assistant Professor, Department of Electronics and Communication Engineering, Bharath Institute of Higher Education and Research, Chennai, India.

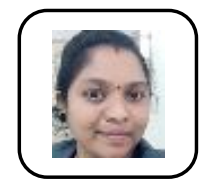

Sowmiya Manoj, Assistant Professor, Department of Electronics and Communication Engineering, Bharath Institute of Higher Education and Research, Chennai, India.

Ramya Assistant Professor, Department of Electronics and Communication Engineering, Bharath Institute of Higher Education and Research, Chennai, India. 